\title{
28. LEG 40 RESULTS IN RELATION TO CONTINENTAL SHELF AND ONSHORE GEOLOGY
}

\author{
William G. Siesser, Department of Geology, University of Cape Town, Rondebosch, South Africa
}

\section{INTRODUCTION}

This study compares and contrasts the sedimentary history of the onshore coastal region and the continental shelf along the west coast of South Africa, South West Africa, and Angola with that of the outer continental margin of those countries (Figure 1), as shown by Leg 40 drilling.

\section{Geologic Setting: Mesozoic and Tertiary Sedimentation}

Southern Africa underwent its last orogenic phase during the Triassic, raising up the Cape Fold Belt. Although no further orogenies occurred, southern Africa remained a high continental mass throughout the Mesozoic and Cenozoic owing to repeated epeirogenic uplift. Epeirogenesis had a characteristic and repeated pattern: maximum uplift occurred in a zone near the coastal margin (somewhat seaward of what is now the Great Escarpment), resulting in a steep seaward tilting on the outer side and a gentler inland tilting towards the interior (Truswell, 1970).

De Swardt and Bennet (1974) have refined this general model by suggesting that the uplifted zone was originally initiated by graben faulting associated with rifting of Gondwanaland. The shoulders of the graben sloped strongly (seaward) toward the rift and more gently (landward) away from the rift. This is analogous to the pattern shown by more recent rift faulting in central and east Africa. The original fault scarp was gradually eroded back (landwards) and is now represented by the irregular Great Escarpment (Figure 1). Thus sediments derived from the periodically uplifted areas were transported both inland, to rest in continental basins (e.g., the Kalahari and Etosha basins), and seaward to rest in oceanic basins (e.g., the Orange Basin) (Figure 1).

Few Mesozoic and Tertiary sediments are found in the coastal area south of the Kunene River, largely owing to the paucity of post-Paleozoic sedimentary basins along the coast of southwestern Africa which could have acted as sites of accumulation. Scrutton and Dingle (1974) have proposed reasons for the lack of sedimentary basins along this coast. Two factors are probably responsible: (1) In the region between Saldanha Bay and Cape Agulhas, relatively low-density granitic plutons have precluded extensive sedimentation because of their buoyant nature. (2) The coast to the north has repeatedly been uplifted along the Great Escarpment hinge line, thus maintaining a steep gradient in the continental basement. This, together with the lack of any large positive features paralleling the coast which might act as sediment dams (Scrutton and Dingle, 1974), has prevented the forma- tion of basins; instead a sediment wedge has prograded seaward in a deltaic fashion (Scrutton and Dingle, 1974). However, there is some suggestion that marginal-fracture zones striking perpendicular to the coast have acted as lines of differential subsidence, thus exercising some control over the movement of sediments parallel to the coast (Scrutton and Dingle, 1974).

This situation is in contrast to the Cuanza Basin of Angola, where sedimentation has been controlled by a marginal basement plateau, a number of basement highs, and salt structures (Scrutton and Dingle, 1974).

\section{Onshore}

Only two Cretaceous exposures have been reported between Cape Agulhas and the Kunene River. The southernmost is a deposit of nonmarine clayey sands (with calcareous concretions) containing bones of the dinosaur Kangnasaurus coetzeei, calcified and silicified wood, and streaks of lignite (Rogers, 1915). These sands are found just south of the Orange River and were originally thought to be correlatable with a Coniacian bed at Bogenfels (Haughton, 1930a), but later were considered to be probably Lower Cretaceous in age (Haughton, 1969, p. 428).

The only known Cretaceous marine rocks outcrop near Bogenfels (Figure 1) at a height of 60 meters. These consist of a massive limestone, containing abundant Exogyra sp., and marly silts. The beds were assigned a middle to upper Eocene age by Böhm (quoted in Haughton, 1930a), but Haughton (1930a,b, 1963, 1969) discovered a single ammonite specimen, Placenticeras merenskyi, which suggested a Senonian, "probably Coniacian" age.

North of the Kunene, Cretaceous rocks outcrop in the Mossamedes and Cuanza basins (Figure 1). Onshore outcrops in the Mossamedes Basin are limited to a narrow strip of rocks along the coast, whereas the Cuanza Basin extends up to $150 \mathrm{~km}$ inland. These basins largely underlie the continental shelf, and the following descriptions thus pertain to the shelf as well-an area well known from offshore oil exploration. The lithology of the sediments is described in detail by Franks and Nairn (1973); only the gross aspects of the stratigraphic relationships and lithologies will be presented here, summarized from Franks and Nairn (1973).

The Mossamedes Basin (1-2 km thick) is separated from the Cuanza Basin (up to $4 \mathrm{~km}$ thick) by Precambrian rocks of the Luanda swell. The subsurface nature of the sediments in the Mossamedes Basin is poorly known, compared to that of the contiguous Cuanza Basin to the north. Moreover, the same formation 


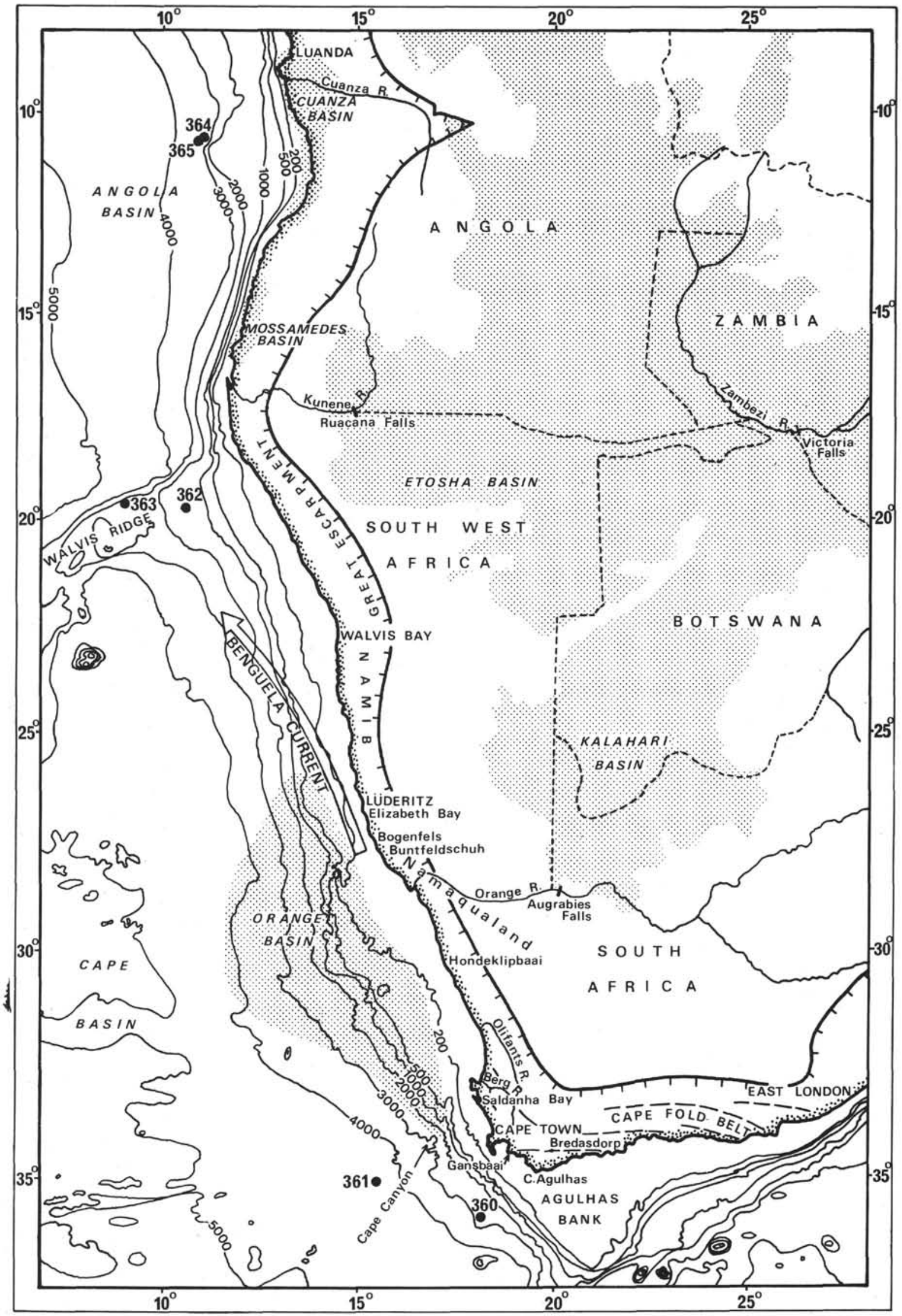

Figure 1. Location map showing localities and features mentioned in the text. Isobaths in meters. 
names have been used for both basins (Franks and Nairn, 1973). The following summary of lithofacies in the Cuanza Basin will therefore serve for both basins.

In the Cuanza Basin three stratigraphic units are recognized: (1) a basal unit of continental and lagoonal rocks, mostly sandstones and conglomerates, with calcareous, argillaceous, and evaporitic layers. Their age is not well established, but is believed to be Aptian or pre-Aptian. This unit is suspected to underlie much of the continental shelf and slope (Emery et al., 1974). (2) The basal unit is overlain by a thick sequence of Aptian-Albian lagoonal evaporites-halite, anhydrite, and dolomite-overlain by dark gypsiferous clays grading upwards into dolomitic and oolitic limestones. The base of this unit is massive halite, originally an estimated 1500 meters thick. It has been suggested (Roberts, 1975) that the salt is developed partly over oceanic and partly over continental crust. Roberts (1975) suggests a deep basin, "so that salt deposition took place either by dessication (sic) or by precipitation from saturated deep-water brines." In any case, the evaporites were laid down in long narrow arms of the ocean, which gradually widened (Emery et al., 1974). The salt has been mobilized to form the salt diapirs reported by Emery et al. (1974). Vertical movement probably began during the Albian, but continued until Miocene times owing to continual sediment loading. (3) The uppermost sedimentary unit is composed of normal marine marls, clays, and limestones, ranging in age from Cenomanian-Turonian to lower Miocene.

Numerous Cretaceous hiatuses exist in the Mossamedes Basin but are not present in the Cuanza. This is partly because mapping has been restricted to marginal areas of the Mossamedes Basin. These minor hiatuses are known from late Albian to Senonian times.

Tertiary sediments occur sporadically along the coast south of the Kunene. Remnants of the MiocenePliocene Bredasdorp Formation crop out near Gansbaai, and again near Saldanha Bay (Figure 1). These are shallow sublittoral and littoral massive to thick-bedded calcarenites, often containing a pebble or shell bed at the base, and are never more than a few meters thick along this part of the coast. The marine limestones are overlain by lithified calcareous dunes of Pleistocene age (Siesser, 1972).

Another Miocene rock unit, the Saldanha Formation (Tankard, in press), also crops out just south of Saldanha Bay. This formation consists of a 1-meterthick phosphatic sandstone of middle Miocene age. The formation is underlain by unnamed, alternating freshwater, marine and terrestrial (?) clays, sands, and carbonaceous silts (Tankard, in press). A similar phosphatic sandstone exists at Hondeklipbaai. It has not been well dated, but a late Miocene age has been suggested (Tankard, 1974).

The Saldanha Formation is unconformably overlain by the Pliocene Varswater Formation. This formation varies in thickness from 10-43 meters, and, from the base upward, consists of deltaic kaolinitic clays, beach gravels, fluvial and estuarine sands, and marine phosphatic-pelletal sand (Tankard, 1974). The gravels contain littoral molluses, and large numbers of terrestrial and aquatic animals are found in the fluvial and estuarine sands. The first fossil penguin from Africa, the first bear from sub-Saharan Africa, the only known giant pig from South Africa and other unusual fauna are found mixed in this deposit. To explain the association of this variety of animals, Hendy (1973) suggests a grasslands-surrounded river, with forested banks, emptied into the sea in this vicinity. The mammal assemblages suggest an age of 4 to 4.5 m.y.B.P., based on similar East African faunas.

A pelletal phosphorite, possibly correlatable with the Varswater Formation, is located at Hondeklipbaai (Tankard, 1974). However, no further marine onshore Tertiary rock units have been proved between Hondeklipbaai and Buntfeldschuh, with the possible exception of the "Oyster Line" raised beach. This beach stands at 25 meters or more just south of the Orange River, but is warped down to 9 meters to the north, an elevation it more or less maintains in sporadic ourcrops as far north as the Kunene. The "Oyster Line" is named for the abundant Ostrea prismatica it contains; Donax rogersi and Chamelea are also common. This beach may be late Pliocene in age, although most investigators favor early Pleistocene (Haughton, 1969).

Scattered Tertiary outcrops are found in South West Africa. The following four paragraphs are summarized from Haughton (1963, 1969). Martin (1973), and W.G. Siesser (unpublished data).

The outcrops lie up to $16 \mathrm{~km}$ inland and stretch northward from Buntfeldschuh for some $90 \mathrm{~km}$. At Buntfeldschuh there is a surf-cut platform at $120-140$ meters upon which rests about 45 meters of probable marine Miocene sediments. This unit consists of a sporadic pebble conglomerate at its base, overlain by marly or clayey fine-grained sandstones containing occasional lenses of chalcedony, agate, and jasper pebbles. The only fossils are fish remains and burrows. Assignment to the Miocene is on the strength of a lithologic correlation with similar, but fossiliferous, beds at Bogenfels.

At Bogenfels, Tertiary remnants are exposed in small valleys at a height of about 70 meters. These sediments are clayey silts and a coquinoid limestone overlying a pebble layer. They contain abundant Crassostrea, Mya, Turritella, Mactra, and the nautiloid Aturia lotzi (Haughton, 1969). The sediments were deposited in a shallow-marine environment and are Eocene or Miocene in age (Haughton, 1969). Also near Bogenfels are fluviatile marly sandstones containing bones of rhinoceroses, pigs, antelopes, rodents, and hyracoids, probably of lower Miocene age (Haughton, 1969).

The "Pomona beds" crop out some $15-20 \mathrm{~km}$ north of Bogenfels. They consist of a pebble conglomerate overlain by clayey or calcareous sandstones containing occasional pebble stringers. The sandstones are capped by dolomitic silcrete and calcrete and the section is up to 35 meters thick. The sandstones are probably mostly fluvial in origin; post-depositional silcretization and calcretization suggest arid conditions. These beds are not well dated, but are known to be pre-lower Oligocene in age. 
Near Elizabeth Bay a thin (up to $15 \mathrm{~m}$ ) sequence of slightly dolomitic clays and coarse sandstones are exposed (the Elizabeth Bay Formation [Greenman, 1969]). At their seaward edge these may be shallowmarine facies, but grade landward into a fluvial facies. Terrestrial mammal remains found in this unit are considered to be Miocene in age (Q.B. Hendy, personal communication). No Tertiary outcrops are known between Elizabeth Bay and the Kunene River.

In the Mossamedes Basin, Paleocene rocks are absent. An Eocene transgression deposited radiolarian and foraminiferal limestones, chalks, and marls at elevations up to 250 meters. Oligocene rocks have not been found, but Miocene sandstones, limestones, and marls underlie late Pliocene (?)-Pleistocene neritic facies (Franks and Nairn, 1973).

The Cuanza Basin sequence is, again, better known. The marine deposition which began in Late Cretaceous times continued without interruption through the Eocene, depositing limestones and marly siltstones in the Paleocene, and shales, siltstones, and chalk during the Eocene; the uppermost shales contain chert. No Oligocene sediments have been found. In the Miocene, gypsiferous shales grade upward into dark shales, sandy coquinoid limestones, and sandstones. Fluvial, deltaic, and littoral sediments cover the marine Miocene beds, which are conformably overlain by the late Pliocene (?)-Pleistocene sediments found in the Mossamedes Basin (Franks and Nairn, 1973).

\section{Continental Shelf}

The writer is unaware of any surface mapping of the continental shelf off Angola; south of the Kunene River the shelf has been mapped in some detail (see Siesser et al., 1975, for a review).

Precambrian and Paleozoic rocks form a narrow rocky platform extending from the shoreline to a few kilometers offshore. The platform is bounded on its seaward edge by a steep cliff which varies from 5 to 25 meters in height. Basement rocks are found seaward of the scarp in the same areas, especially around and south of Saldanha Bay. Seaward of the rocky platform, Cretaceous rocks crop out from at least the Orange River in the north to Saldanha Bay in the south. South of Saldanha Bay the Cretaceous rocks have been overstepped by Paleogene rocks, with only a few isolated Cretaceous inliers still exposed. The Cretaceous is probably also overstepped north of the Orange River, as its presence on the shelf has not been proved to the north. This Cretaceous outcrop band consists mostly of poorly fossiliferous conglomerates, sandstones, and siltstones. Their assignment to the Cretaceous is based on seismic reflection profiling (Dingle, 1971, 1973a), where datable Paleogene rocks can be seen unconformably overlying these siliceous rocks.

Seaward of the Cretaceous belt, Paleogene rocks out crop. These rocks are poorly known, but seem to be mostly (1) localized deltaic facies, (2) nearshore-marine glauconitic clays and quartzose limestones, or (3) phosphorites (some of these may, however, be Neogene in age). Paleogene rocks are sporadically overlain by mid-shelf Neogene sediments from south of Cape
Agulhas to Saldanha Bay; north of Saldanha Bay these Neogene sediments blanket the margin from the midshelf seaward. These sediments are mostly glauconitic and phosphatic limestones and marls, containing rich assemblages of planktonic foraminifers and calcareous nannofossils (Siesser, 1975).

The shelf is now being covered on its shoreward edge by a relatively narrow band of modern terrigenous sediments, mostly brought to the sea by the four perennial rivers along this coast: the Berg, Olifants, Orange, and Kunene. Late Cenozoic residual and relict sands mantle large parts of the middle and outer shelf, grading into Quaternary pelagic mud on the outer shelf.

A double shelf break exists along parts of this west coast. The fact that the outer shelf break is "one of the deepest in the world" $(400-500 \mathrm{~m})$ is widely quoted. Dingle (1973a) has shown that the western continental margin had attained its basic present-day outline by the end of the Cretaceous: the outer shelf break is and was the seaward edge of an upward-and outward-built wedge of Cretaceous sediments. Differential uplift of the Great Escarpment hinge-line area probably caused the western margin to subside relative to the continental interior (Scrutton and Dingle, 1974). Tertiary sediment loading may have aided subsidence. This is in contrast to the southern margin of South Africa, which has apparently remained more stable (Dingle, 1971). The shelf break (120-180 m) off the south coast (actually an "inner shelf break") is an erosional scarp cut into Neogene limestones (Dingle, 1973c). However, an expression of an ancient Mesozoic shelf break (i.e., an outer shelf break) may be seen on the continental slope (Dingle, 1973c, p. 9). Dingle (1973a and personal communication) believes that the top of the shelf was planed by erosion during Maestrichtian or early Paleocene times. Horizontal Paleogene sediments, probably laid down during a Paleocene-Eocene transgression, are now found on this planed surface. An (?) Oligocene erosion surface separates these horizontal beds from an overlying seaward-dipping Neogene sequence. Morphology of the inner shelf break suggests that it is probably depositional, i.e., the seaward front of a prograding late Neogene sediment wedge, shaped and modified by erosion. The depth of the southern inner break suggests scouring by submarine currents to account for at least a part of the erosion.

During the Cretaceous, sediment discharge from the Orange and other southern rivers could freely move to the south because of southerly directed currents or the general absence of currents. With the development of the Benguela Current system during the Oligocene, much of the sediment discharge from these rivers began to move in a northerly direction, a pattern continued through the Neogene to the present. Today the traction load moves northward by longshore drift, some of it eventually moving back onshore to form part of the Namib Sand Sea (J. Rogers, personal communication). Much of the suspension load is deposited in a small delta at the mouth of the Orange River, and the rest is moved out over the shelf.

The only sedimentary basin known to underlie the continental margin between Cape Agulhas and the Kunene River is the Orange Basin (Dingle 1973d). This 
represents the wedge of mostly Mesozoic sediments (up to $3.8 \mathrm{~km}$ thick) overlain by up to 800 meters of Paleogene sediments and 300 meters of Neogene sediments. The Cretaceous beds are gently folded and are unconformably overlain by Paleogene rocks, which are in turn unconformably overlain by Neogene rocks (Dingle, 1973a).

In vertical section the sediments from Cape Agulhas to Angola can be divided into several stratigraphic units separated by prominent acoustic reflectors. Emery et al. (1975) divided the sediments as follows: (1) basement to Horizon AII (Mesozoic, mostly Cretaceous); (2) Horizon AII to Horizon D (Paleogene); and (3) Horizon D to the sediment surface (Neogene). (These ages may now be revised on the basis of Leg 40 drilling.) They found that the two seismic reflectors, named "AIl" (for R/V Atlantis II) and "D" (for R/V T.B. Davie), could be traced seaward down the continental slope and across the continental rise, onto the Abyssal Plain. The reflectors could also be traced in a north-south direction from Cape Agulhas to the Walvis Ridge (Emery et al., 1975). AII can be traced even further into the Sierra Leone Basin off West Africa, and some West African profiles contain a prominent reflector in the uppermost deep-sea sedimentary unit which may be correlatable with the D-horizon in the Cape Basin (Emery et al., 1974).

\section{Outer Continental Margin}

Mesozoic stratigraphy on the outer continental margin (lower slope and rise) is known from drilling at DSDP Sites 361, 363, and 364 .

Starting in the south at Site 361 , Lower Cretaceous sediments are mostly highly carbonaceous (average about 5 wt\% inorganic carbon) shales, sandy mudstones, and sandstones, with minor mudstones, siltstones, and one marly nannofossil chalk. These sediments become less carbonaceous in uppermost Lower Cretaceous times, and the lithology becomes dominated by a sequence of grayish black mudstones, alternating with reddish mudstones and claystones. Most of this unit is fissile and the term "shale" is appropriate. Minor amounts of sandy mudstones, sandstones, and one chalk bed are also present. This lithology continues from uppermost Lower Cretaceous through Upper Cretaceous without break. A distinctive characteristic of the shales is the abundance of parallel and cross-bedded fine sand and silt laminae in the mudstones, which increase in frequency in younger beds of the Upper Cretaceous. This Cretaceous section appears to be complete with no stratigraphic breaks from lowermost Aptian to Maestrichtian. Total thickness is about 1000 meters.

At Site 363 on the Walvis Ridge, Aptian sediments are pelagic limestones, marly limestones, chalks, and minor mudstones. About 1 meter of shallow-water limestone (indicated by the presence of rounded limestone clasts and fragments of calcareous algae) was found in the lowermost core. The same pelagic limestones, chalks, and mudstones dominate the Upper Cretaceous, with the less-indurated chalks becoming more common in the younger part of the Upper Cretaceous. The Coniacian to Maestrichtian section is continuous, but some Cenomanian and Turonian sediments are believed to be missing. The Cretaceous section cored has a thickness of just over 400 meters.

Site 364 in the Angola Basin reached Lower Cretaceous (Aptian) dolomite, and black carbonaceous shales. These facies continue into the lower Albian, grading into pelagic limestones, marly limestones, chalk and minor carbonaceous mudstones in late Albian-Santonian times. Campanian and Maestrichtian sediments are nannofossil chalk and marly chalk at Site 364. The total Cretaceous section here is about 700 meters thick; no stratigraphic breaks were found.

The Tertiary in the Cape Basin begins with Paleocene pelagic clay containing zeolites and fish remains. This is overlain by marly nannofossil ooze, a lithology which continues into the Eocene. Younger Eocene lithologies also comprise calcareous mud, mud, and marly nannofossil chalk. Nannofossil chalk is the overwhelmingly dominant lithology in the Oligocene and Miocene, grading into a less-indurated nannofossil ooze in the upper Miocene and Pliocene. Paleogene sediments have a thickness of approximately 400 meters.

Paleogene sediments at Sites 362 and 363 are pelagic limestones, marly limestones, marls, chalks, and nannofossil oozes. One thick layer of white Braarudosphaera chalk/ooze is a lower-middle Oligocene marker bed in this area. No stratigraphic breaks were proved, although absence of the basalmost Paleocene is suspected. The Paleogene section is 285 meters thick.

In the Angola Basin, Paleogene sediments are mostly nannofossil chalk and marly nannofossil chalk, with an influx of zeolite-bearing pelagic clay and radiolarian mud in the middle Miocene. The lower Miocene, Oligocene, and upper Eocene are missing. The condensed Paleogene section is approximately 200 meters thick.

Neogene sedimentation from the Cape Basin to the Walvis Ridge (Sites 360,362 , and 363 ) is dominated by nannofossil chalk or ooze in the Miocene and nannofossil ooze in the Pliocene. On the Walvis Ridge both the chalks and oozes are more marly, and contain abundant diatoms from the upper Miocene to the Pleistocene. No stratigraphic breaks were found; the Neogene and Quaternary section is 400 meters thick in the Cape Basin and 800 meters thick on the Walvis Ridge. Miocene sediments are particularly thick: 300 meters in the Cape Basin and 650 meters on the Walvis Ridge.

Neogene sedimentation was much more terrigenous at Site 364: the pelagic clay found in the upper Oligocene continues into the Miocene, grading upward into zeolite-bearing muds and marly nannofossil oozes. Calcareous mud and clay predominates in the upper Pliocene. No stratigraphic breaks are found. The Neogene and Quaternary section is about 150 meters thick.

\section{EARLY CRETACEOUS}

We begin southern Africa's hsitory in the Early Cretaceous at the time of rifting from South America. Larson and Ladd (1973) believe the time of initial open- 
ing of the South Atlantic was about 127 m.y.B.P. (anomaly M-12) and the spreading half-rate from 127 to $110 \mathrm{~m} . \mathrm{y}$. was $1.6 \mathrm{~cm} / \mathrm{yr}$. The final separation (by shearing) of the Falkland Plateau and southern Africa occurred somewhat later (about 103 m.y.B.P., Dingle and Scrutton, 1974).

Rifting was almost certainly accompanied by volcanism, in all likelihood represented by the Kaoko Lavas (tholeitic basalts) in South West Africa (peak at 125 m.y.B.P.) and the Sierra Geral basalts in Brazil (peak at 120 m.y.B.P.) (Siedner and Miller, 1968). Marsh (1973) has described the alkaline igneous complexes which form lineaments in Angola, South West Africa, Brazil, and Uruguay. Each of these lineaments can be correlated with a unique fracture zone/transform fault offsetting the Mid-Atlantic Ridge. The age range (120-135 m.y.B.P.) suggests that this volcanism developed along the continental extensions of these major transform faults during the initial rifting of the South Atlantic.

During the Early Cretaceous the southern African subcontinent was still highstanding but was being denuded by the "Gondwana" erosion cycle (King, 1967), which began in the Jurassic and is a feature of all the Gondwana continents. A new cycle of upwarping and erosion, termed the "Post-Gondwana" phase by King (1967), begun at the time of rifting. The incipient Great Escarpment-which today stretches along the west coast from the Cape Fold Belt into Angola-probably also originated at the time of rifting (De Swardt and Bennet, 1974). Emery et al. (1975) have noted that strata below the AII reflector (i.e., preAlbian) on the continental margin are folded in places, although this deformation may have occurred later.

There are almost no Lower Cretaceous rocks onshore south of the Kunene to record climatic conditions during the Early Cretaceous. A possible exception is the Kangnasaurus-bearing deposit, which suggested to Rogers $(1915,1922)$ that the Lower Cretaceous may have been wetter on the west coast than during following times. Rogers (1915, 1922) suggests that a decrease in rainfall during the late Cretaceous or early Tertiary allowed the valley containing the Kangnasaurus bones to be filled with local debris. Nor has subsequent rainfall in this area been sufficient to re-excavate the valley. However, Mabbutt (1955) has suggested that the inactivity of these streams may simply reflect the invasion of blown sand rather than inadequate rainfall.

Korn and Martin (1937) believe the Jurassic and earlier Cretaceous were times of aridity in South West Africa, but this is based solely on the presence of silicification (agates and carnelians) lying on an assumed "old" Cretaceous pediplain.

The paleogeographic reconstruction of Dietz and Holden (1970) places the southern tip of Africa at almost $60^{\circ} \mathrm{S}$ and the Walvis Ridge abutment at almost $40^{\circ} \mathrm{S}$, suggesting temperatures cooler than today. However, the Lower Cretaceous sediments cored at Site 361 provide the best indication of the onshore climate. The ubiquitous and abundant presence of plant debris (average of just over 10\%) in the Aptian would at first seem to suggest a temperate climate and well-vegetated sourceland. The presence of wood and lignite in the Kangnasaurus sands onshore seems to bear this out. However, strong doubts of a wet Lower Cretaceous climate have been raised by analysis of the palynomorphs from Site 361. McLachlan and Pieterse (this volume) find that the Lower Cretaceous is overwhelmingly dominated by Classopollis pollen from coniferophytes. The low diversity of species, and especially the low percentage of fern pollen, suggest a harsh (probably dry) climate. The Angolan climate was probably warm and semi-arid to arid, as indicated by the presence of similar pollen at Site 364 (Morgan, this volume), as well as the presence of evaporites in the Cuanza Basin.

\section{Sedimentation}

We should expect the rifted African margin to contain early formed rift-generated grabens and horsts striking parallel to the direction of rifting. These would form traps for continental sediments prior to invasion by the sea. No such sediment-filled grabens have yet been found south of the Kunene, but probably lie buried somewhere on the continental margin (possibly in the inner Orange Basin?). North of the Kunene, we have seen that continental sandstones and conglomerates were deposited in early fractures developed in the Mossamedes and Cuanza basins. The axis of Lower Cretaceous sedimentation lay well inland of the present coastline at that time (Franks and Nairn, 1973). No sedimentation rates are available for these continental deposits.

The uplifted continent continued to be stripped of sediment, which was carried seaward by the protoOrange, Kunene, Cuanza, and other rivers. These are King's (1967) "Post-Gondwana" sediments. The thick Cretaceous deposits in the Orange Basin (Dingle, 1973a) began (or continued) to accumulate, rapidly upbuilding and blocking out the shape of the continental margin. Dingle (1973a) has used $3 \mathrm{~km}$ for the thickness of an ?Aptian-?Maestrichtian sequence on the mid and inner shelf to give a sedimentation rate (recalculated here) of about $64 \mathrm{~m} / \mathrm{m} . \mathrm{y}$. for that time interval.

The major supplier of terrigenous sediment to the southern continental shelf and Cape Basin was (and is today) the Orange River. Today this river discharges an average of about 60 metric tons/yr (Rooseboom and Maas, 1974), with an estimated traction load equal to $25 \%$ of the suspension load (Midgley, 1952) (Cretaceous discharge was probably considerably higher, judging by sedimentation rates calculated for the Orange and Cape basins.) Much of the present-day sediment is transported to the north by strong northerly directed currents and swell; a weak, southerly flowing inshore counter current also moves some of the suspended material to the south. It is unlikely that the strong northerly currents were developed before the Oligocene (see "Paleogene" section). Southerly directed currents or an essential absence of currents-thus allowing a multidirectional diffusion of sediment-allowed the transport of an abundant Cretaceous terrigenous fraction as far south as Site 361 . 
South of the Walvis Ridge terrigenous sediment spilled across the developing continental shelf to eventually reside in the narrow confines of the poorly oxygenated proto-Cape Basin (a contribution may also have been coming from South America). The Falkland Plateau had not yet completely separated from the southern tip of Africa and oceanic access was limited. Similarly, the Walvis Ridge was forming an effective barrier to circulation between the Cape and Angola basins. Restriction was sufficient to allow a thick (up to $2 \mathrm{~km}$ ) evaporite body to accumulate in Aptian times in the Angola Basin but not in the Cape Basin, where only euxinic shales, siltstones, and mudstones were deposited. The Walvis Ridge was standing high and appears to have been largely isolated from sediment coming from the African shelf. Nor did it receive any sediments indicative of a restricted marine phase.

Sedimentation rates cannot be accurately calculated for the Lower Cretaceous on the outer margin (Site 361), since the Lower-Upper Cretaceous boundary has not yet been established. However, if one arbitrarily chooses core 25 as Albian (see Site 361 Summary) a sedimentation rate of about $38 \mathrm{~m} / \mathrm{m}$.y. is obtained. On the Walvis Ridge, this rate is at least $23 \mathrm{~m} / \mathrm{m} . \mathrm{y}$., and in the Angola Basin it is about $40 \mathrm{~m} / \mathrm{m} . \mathrm{y}$.

The acoustic reflector "AII" (Emery et al., 1975) was traced down the continental slope to Site 361. Coring proved it to be the top of the Aptian euxinic sequence at this site, but this reflector may well change both its lithology and age from area to area. Emery et al. (1975, p.46) believed it to be of Upper Cretaceous to middle Paleocene age in the Cape Basin, but Senonian in age in the Sierra Leone Basin (Emery et al., 1974, p.68). AII could not be established at Sites 363 and 364 .

\section{LATE CRETACEOUS}

Epeirogenic uplift of the continent occured again in early Late Cretaceous times (King, 1967; Truswell, 1970), regenerating erosion of the still high continental mass, and initiating King's (1967) "African" erosion cycle-a cycle that was to continue until the end of the Oligocene (Truswell, 1970).

The half-rate of South Atlantic sea-floor spreading is believed to have increased markedly during the Late Cretaceous, to $4.5 \mathrm{~cm} / \mathrm{yr}$ for the period $110-85$ m.y.B.P. (Larson and Ladd, 1973), then slowing to just over 2 $\mathrm{cm} / \mathrm{yr}$ from $85 \mathrm{~m} . \mathrm{y}$.B.P. to the present. This slowing is attributed to the shift of the Early Cretaceous pole of rotation at $21.5^{\circ} \mathrm{N} 14^{\circ} \mathrm{W}$ to its present position at $67.3^{\circ} \mathrm{N} 39.5^{\circ} \mathrm{W}$, which occurred about 80 m.y.B.P. Le Pichon and Hayes (1971) believe the northward movement of the pole occurred after mechanical restraints present during early opening of the ocean were relaxed.

Renewed volcanic activity probably took place along the South America-Mid-Atlantic Ridge-Southern Africa lineament/transform fault line (Marsh, 1973). Age dates from Brazil show magmatism between 51 and 83 m.y.B.P., and Marsh (1973) believes similar ages will be established in Angola and South West Africa when dates are obtained. Marsh also attributes the renewed magmatism to stresses caused by the shift of the Cretaceous pole of rotation at 80 m.y.B.P.
There is little evidence by which to interpret the climate of western southern Africa during early Late Cretaceous times. Extrapolation from the reconstruction of Dietz and Holden (1970) suggests a latitude of about $55^{\circ} \mathrm{S}$ for the tip of South Africa during Cenomanian times, with northward drift to about $48^{\circ} \mathrm{S}$ by Maestrichtian times.

Du Toit (1954) believes the interior portion of all of South Africa has been dry since the beginning of the Jurassic. The margins may have been quite different. The climate must have been fairly wet in the southeastern parts of South Africa, as shown by the abundant plant remains-ferns, cycads, and conifersin the "Marls and Wood Beds" (Du Toit, 1954). In the west, less evidence exists. Korn and Martin (1937) believe humid conditions and the development of a wide, shallow river system began in South West Africa during the Late Cretaceous. They interpret these conditions on the basis of valley shapes and the accompaniment of "groundwater karst."

Palynomorph studies at Site 361 support a warm/wet onshore climate. Upper Cretaceous sediments (McLachlan and Pieterse, this volume) contain a high diversity of pollen, including a high percentage of fern pollen, suggesting wetter climate than that of the Lower Cretaceous.

\section{Sedimentation}

During the Late Cretaceous, we see the first evidence of the sea moving across the present coastal fringe. Kennedy and Klinger (1971) have documented a major unconformity during the early Upper Cretaceous in southeastern Africa (Natal and Zululand); Upper Cenomanian and Turonian rocks are both absent, probably caused by a late Cenomanian regression. Dingle and Scrutton $(1974$, p. 1471) believe this regression was late Albian, but this timing overlooks the presence of lower Cenomanian rocks (Kennedy and Klinger, 1971). It is interesting to note that some Cenomanian and Turonian sediments may be missing from the Walvis Ridge at Site 363. This site need not have been subaerially exposed to account for the removal-in all likelihood current velocities would be intensified by the lowered sea level, resulting in submarine erosion over this topographic high. Any Lower Cretaceous or early Upper Cretaceous sediments that may have been deposited onshore south of the Kunene would also be susceptible to removal during the Cenomanian regression. Numerous hiatuses occur in the Mossamedes Basin during this time interval (including breaks in the Cenomanian, Turonian, and Senonian), but the better-known Cuanza sequence appears to be complete (although Cenomanian rocks are somewhat doubtful - Franks and Nairn, 1973).

The first recorded encroachment of the sea onto the coastal area south of the Kunene was during Coniacian times, as inferred from the Bogenfels outcrop. This transgression may have been caused in part by rapid lowering of the land mass by erosion following the initiation of the "African" erosion cycle. The general lithofacies pattern for this Coniacian time slice is: limestones and marly silts onshore (Bogenfels), grading 
into sandy limestones, sandstones, and siltstones on the inner continental shelf, to shales on the middle shelf and outer continental margin (Site 361).

Sedimentary structures at Site 261 suggest that large deep-sea fans built out over the outer continental margin in the south. Muddy sediments were channeled down the fan distributaries, developing cut-and-fill, levee overflow, and channel structures. The high rate of sedimentation of the Lower Cretaceous slowed, probably owing to a slowdown of basement subsidence and lowering of sourcelands by the African erosion cycle. A sedimentation rate of $15 \mathrm{~m} / \mathrm{m}$.y. is calculated for the Upper Cretaceous at Site 361.

On the Walvis Ridge, Upper Cretaceous sediments indicate open-ocean conditions, with a minor, but persistent terrigenous influx from the continent. Rate of sedimentation was low ( $6 \mathrm{~m} / \mathrm{m}$.y.). Upper Cretaceous sedimentation was much the same in the Angola Basin-mostly open-ocean sediments, with periodic stagnation of the bottom environment. The sedimentation rate at Site 364 is about $10 \mathrm{~m} / \mathrm{m} . \mathrm{y}$. Onshore, sediments in the Cuanza Basin are also normal openocean marine, suggesting similar oceanic conditions with calcareous biogenic sedimentation prevailing over what is now the Angolan coast, across the continental shelf, slope, and rise as far south as Walvis Ridge.

\section{PALEOGENE}

Localized volcanic activity took place during the Paleogene on the Agulhas Bank ( $58 \pm 2.4$ m.y.B.P.) and near Bogenfels in South West Africa (37 m.y.B.P.) (Dingle and Gentle, 1972). A. Du Plessis (personal communication) has found sub-sea-floor igneous intrusions on the continental shelf off the Olifants River which he believes are Paleogene in age. This igneous activity was probably related to a period of deformation, as strong folding of pre-Neogene rocks can be seen on seismic records (Dingle 1973a). The African erosion cycle which began in Late Cretaceous carried through to at least the end of Oligocene times, denuding the continent and shedding large amounts of sediment both inland and seaward (King, 1967). The Great Escarpment was greatly enlarged during Tertiary times (King, 1967).

The reconstructions of Dietz and Holden (1970) suggest that Africa was closely approaching its presentday latitude during the Paleogene. Onshore evidence for the Paleogene climate is meager. Korn and Martin (1937) believe that the wet climate in South West Africa during Late Cretaceous times continued into the Eocene, with arid conditions developing in the Oligocene or early Miocene, in part shown by the silcretization and calcretization of the Pomona beds. Mabbutt (1955) believed Namaqualand was wetter than today during early and middle Tertiary times, based on an interpretation of erosion surfaces and assumed ages of surface deposits.

The reconstruction of Eocene-Oligocene global climates by Franks and Kemp (1972) suggests slightly cooler and drier conditions during the Oligocene than the Eocene for western Southern Africa. Paleocene and Eocene climates probably vary little.
The Cenozoic climate of most of this western part of southern Africa depends on the timing of the initiation of the cold, upwelling Benguela Current. This current condenses moisture in sea breezes and is thus a major factor in precluding rain from the South West African coast today. It undoubtedly had much the same effect in the past. Dingle (1973a) believes the Benguela Current was established in Late Cretaceous times. However, recent evidence relating to the development of the Antarctic glaciation and Antarctic Bottom Water suggests that the Benguela may have been initiated somewhat later.

Van Zinderen Bakker (in press) has suggested that the cold, upwelling Benguela Current originated in Early Oligocene times, initiating aridification of the west coast of southern Africa and creating, inter alia, the Namib Desert. This timing is largely based on isotopic evidence from Shackleton and Kennett (1975), who found that deep-water temperatures in high southern latitudes were near the present low values by the beginning of the Oligocene, but not before. Van Zinderen Bakker (in press) also believes that only by midTertiary (Oligocene) times did the South Atlantic have sufficient longitudinal width for the establishment of its circular wind and ocean current systems. (Moreover, Van Zinderen Bakker [1976] concludes that the general climatic system of today has persisted since late Oligocene.)

Observations at Sites 360 and 362 support the early Oligocene date for initiation of the Benguela. The Antarctic ice cap began to expand markedly near the Eocene-Oligocene boundary (Kennett et al., 1974) which probably caused the onset of cold bottom-water production. The Antarctic Bottom Water essentially controls the carbonate compensation depth (CCD) in the South Atlantic (see Site 362 Summary), and movement of the CCD can be monitored by microfossilpreservation studies. Cold, corrosive bottom water can thus be shown to have moved into the Cape Basin as far north as the Walvis Ridge by at least middle Eocene times. Some upwelling may have occurred as early as Eocene, but early Oligocene is more likely the time of onset.

Braarudosphaera chalk, which is restricted to the lower and middle Oligocene and is only found at Sites 362 and 363 , may reflect the initiation of upwelling cells. Braarudosphaera bigelowi is normally conspicuously absent from open-ocean deposits (Bybell and Gartner, 1972). One anomalous occurrence of open-ocean Braarudosphaera chalk has, however, been found in the South Atlantic (see Bukry, 1974). Nevertheless, Bukry (1974) notes that the greatest concentrations of this species are in coastal waters and small seas of low salinity, and concludes that this species thrives in waters of unusually low salinity.

Upwelled water is markedly low in salinity; it seems more than just coincidental that this particular stenohyaline plankter should only bloom in vast quantities at exactly the same time the first upwelling is postulated, on independent grounds, for the Benguela Current. Sudden, enormous blooms of single nannoplankters are well known (see Noël, 1965, for ex- 
ample). A geologically sudden onset of low-salinity (even lower than present?) Benguela water may have been the catalyst for the Braarudosphaera bloom. Higher late Eocene-early Oligocene rainfall-and thus increased fresh-water runoff-may also have temporarily reduced normal marine salinity. The reason for decrease of this nannoplankter to negligible quantities by the upper Oligocene is unknown, but may be due to changing oceanographic or climatic conditions.

Another unresolved question is what effect the Circum-Antarctic Current may have had on the development of the Benguela. The Circum-Antarctic Current transports the largest volume of water of any ocean current. Moreover, it circulates completely around the Antarctic and is the only current that mixes the waters of all oceans; thus today, as in the past, it is of major oceanographic and climatic importance.

Initial development of this current resulted from the final separation of Antarctica and Australia in middle or late Oligocene (Kennet et al., 1974). Theoretically it would seem that the Benguela could not develop to any significant extent until the Circum-Antarctic current became sufficiently operative (i.e., in middle or late Oligocene). However, initial rifting between Antarctica and Australia began in the Eocene, and perhaps by early Oligocene enough polar water was flowing into the South Atlantic to initiate the Benguela Current.

\section{Sedimentation}

Basement subsidence along the west coast slowed markedly by Paleogene times. Depocenters had shifted to the continental slope-rise and sedimentation rates were lower than in the Cretaceous. Nevertheless, the wet climate and elevated hinterlands provided conditions for considerable erosion and transport of sediment to the sea.

A regression of the sea from late Maestrichtian times to late Paleocene is suggested by Dingle (1973a) and Dingle and Scrutton (1974), based on interpretation of continental-shelf seismic records. Dingle also suggested that Tertiary sedimentation on the continental shelf began with a late Paleocene-early Eocene transgression, followed by a major regression and erosion at the end of the Eocene, which probably cut the submarine proto-Cape Canyon west of Cape Town. This lowering of sea level may also have had some influence on the intensification of bottom currents during the Oligocene. Dingle (1973a) has used a thickness of 600 meters to estimate the rate of Paleogene sedimentation on the west coast continental shelf. Assuming the Oligocene is absent, this corresponds to $22 \mathrm{~m} / \mathrm{m} . \mathrm{y}$.

In the Cape Basin, a sudden change in sedimentation began in Maestrichtian times and continued into the upper Paleocene. The monotonous shale facies was abruptly replaced by a pelagic clay. Terrigenous supply was sharply reduced and $\mathrm{CaCO}$, failed to accumulate. The reason for the reduction in terrigenous input may be related to progressive lowering of the sourceland and increasing distance of the site from land. The lack of $\mathrm{CaCO}$. suggests that this site was below the CCD during this time interval. Otherwise, Paleogene sedimentation at this and the other Leg 40 sites was predominantly hemipelagic, i.e., oceanic sediments with a minor but steady terrigenous contribution, owing to increased distance from the sourceland.

In the Cape Basin, the Paleogene sedimentation rate was about $12 \mathrm{~m} / \mathrm{m} . \mathrm{y}$. On the Walvis Ridge (Site 363 ) it was slightly less than $7 \mathrm{~m} / \mathrm{m} . \mathrm{y}$., and in the Angolan Basin a minimum of $5 \mathrm{~m} / \mathrm{m} . \mathrm{y}$. (part of the upper Eocene and Oligocene are missing).

The upper Eocene-lower Miocene hiatus at Site 364 is almost certainly caused by submarine erosion: this site was never subaerially exposed and a complete cessation of sediment supply is unlikely. Oligocene rocks are also conspicuously absent in the Cuanza Basin.

Erosion may have been caused by increased bottomcurrent intensity, possibly in late Oligocene times. It is likely that stronger currents were in turn related to increased growth and seaward extension of the Antarctic glaciers which began about this time. This would generate a stronger current of cold bottom water flowing to the north. A lowered sea level, owing to Oligocene regression, may also have acted to increase the current intensity.

The "D" reflector (Emery et al., 1975) was seismicly traced down the continental slope and drilled at Site 361. It is an upper Paleocene nannofossil chalk at this position, but, like AII, probably varies in both age and lithology from area to area.

\section{NEOGENE}

At the end of the Oligocene (or earliest Miocene) and again towards the end of the Miocene there was further epeirogenic uplift (King, 1967, 1972; Truswell, 1970), which initiated the "Post-African" erosion. This erosion surface covers more area than any other in Africa (King, 1967). The final major epeirogenic uplift of southern Africa began at the end of the Pliocene and has continued during the Quaternary; it may still be active today (Truswell, 1970). This last uplift rejuvenated coastal rivers which deeply incised their gorges. The point to which erosion of the Orange River gorge has reached is marked by the Augrabies Falls, the Kunene by the Ruacana Falls, and the Zambesi by the Victoria Falls (all knickpoints).

A considerable amount of east-west differential uplift occurred during the Neogene. The marine MiocenePliocene Alexandria and Bredasdorp Formations (considered to be correlatable by Siesser [1972]) reach an elevation of 366 meters near East London, 76 meters near Bredasdorp, and 35 meters at Saldanha Bay. Subsidence of the west coast and/or uplift of the southeast coast has also been suggested by Haughton (1969), Dingle (1973a), and Tankard (1974).

Mabbutt (1955) believes Namaqualand was even drier than present during most of the Neogene, based on the widespread development of calcretes. However, a short period at the end of the Pliocene (or early in the Pleistocene) may have been somewhat wetter, as indicated by renewed stream incision.

Korn and Martin (1973) believe that an arid climate prevailed in South West Africa from Miocene times to the present, with one possible "humid" interval in the 
early Pleistocene. However, more temperate local conditions in the lower Miocene are suggested by the "steppe" assemblage of mammals collected near Bogenfels (Haughton, 1969). Hendy (1973) and Tankard (1974) have also suggested wetter conditions and more luxuriant vegetation during the Pliocene for the Saldanha Bay area, based both on mammal assemblages and sedimentary evidence. Thus it may be that the Neogene climate of the southern African west coast (at least locally) has not been as dry as generally supposed.

\section{Sedimentation}

Only in the Neogene can a definite facies pattern be seen extending from the land, across the continental shelf, onto the outer continental margin. The marine limestones and phosphatic sandstones south of Saldanha Bay and the arenaceous and argillaceous rocks near Bogenfels and Buntfeldschuh have been mentioned previously. These probably represent the landward edge of Miocene and Pliocene transgressions.

Indeed, Dingle (1971, 1973a) has proposed an early or middle Miocene transgression on the continental shelf, followed by regression at the end of the Miocene; a further transgression began in the Pliocene with regression at the end of this Epoch. These transgressions laid down mostly thin, shallow-water calcareous facies on the inner shelf; the beds thicken seawards and change to deeper water calcareous facies. For the mid and inner shelf, Dingle (1973a) has used an estimated Neogene thickness of almost 400 meters to calculate the sedimentation rate. This gives an estimated rate of $18 \mathrm{~m} / \mathrm{m} . \mathrm{y}$.

Dingle (1973a) believes the Pliocene regression eroded much of the late Tertiary strata on the shelf. This erosion may also have generated much of the residual cobbles, boulders and slabs of phosphorite that litter the shelf today. The age of the phosphorites has not been conclusively established, although Dingle (1974) has suggested late Eocene, late Miocene, or late Pliocene as the times when oceanographic conditions (low sea level, upwelling) would have been most favorable for phosphatization. Recent dating of phosphatized limestones (Siesser [1975]) suggests a middle Eocene to middle Miocene age for at least some of the west coast phosphorites.

On the outer continental margin, oceanic sedimentation continued, depositing chalks and calcareous oozes in the Cape Basin and on the Walvis Ridge and calcareous muds and marly oozes in the Angola Basin; the greater terrigenous fraction in the Angolan sediments is the result of input from the large rivers onshore. Neogene sedimentation rates (Quaternary is also included here) were higher in deep waters during Paleogene times: $18 \mathrm{~m} / \mathrm{m} . \mathrm{y}$. in the Cape Basin, 35 $\mathrm{m} / \mathrm{m} . \mathrm{y}$. on the Walvis Ridge (Site 362), and $7 \mathrm{~m} / \mathrm{m}$.y. in the Angola Basin. The extremely high Neogene sedimentation rate on the Walvis Ridge almost certainly reflects vast planktonic productivity resulting from the upwelling which started during the Oligocene. Deposition of diatoms began in upper Miocene times south of the Walvis Ridge, probably as a result of inten- sification in upwelling associated with continued opening of the South Atlantic and the accelerating climatic cooling which began in the Miocene (Berggren and Hollister, 1974, p. 161; Bandy, 1968). The numbers of diatoms remain fairly low throughout the upper Miocene increasing abruptly in the lower Pliocene, an abundance that continues into the Pleistocene. It is interesting to note that almost no $(<1 \%)$ diatoms are found in surface sea-floor sediments adjacednt to Site 362 today (J.M., Bremner, personal communication), although a very rich belt of diatomaceous ooze lies next to the coast, some $230 \mathrm{~km}$ directly shoreward of Site 362. This suggests a shift in the locus of upwelling from Pliocene-Pleistocene to Holocene times.

The much lower sedimentation rates in the Angola Basin suggest upwelling, and thus productivity, was much less north of the Walvis Ridge, confirming that this ridge is a significant oceanographic barrier. The barrier was breached during the Pleistocene, probably during times of glacial maxima. No diatoms were found in the Pliocene or Pleistocene sediments cored at Site 364 , but have been found in late Pleistocene piston cores off southern Angola. This has led Bornhold (1973) to suggest northward extension and intensification of the Benguela Current and its associated primary productivity during the last glacial. Van Zinderen Bakker (1976) discusses the oceanographic and atmospheric conditions which cause the northward expansion of this cold current during glacials.

The continental rise is probably a Neogene construction (Scrutton and Dingle, 1974). Currents have moved sediments across the shelf onto the slope. Slumping (commonly seen on seismic profiles and interperted to be mostly Neogene), and probably geostropic contour currents have aided in building and shaping the continental rise.

\section{SEDIMENTARY HISTORY}

Dingle (in press) has presented an elegant model for the sedimentary history of tensional-clean-break (separation along the line of the original rift) continental margins such as western southern Africa. Briefly, Dingle finds that the migration of sediment depocenters and sedimentary environments is reflected by the rate of sediment accumulation and the degree of marine influence, i.e., non-marine, restricted-marine, or oceanic. The early pre-separation depocenter lies on continental crust and receives non-marine sediments; the sedimentation rate is high, owing to large topographic differences associated with rifting. As the continents separate, the sea moves into the rift. However, the geometry of the narrow basin restricts normal marine circulation, and a variety of restricted-marine sediments accumulate (mostly shallow-water carbonates, euxinic sediments, and evaporites). During this phase, the depocenter progrades across continental crust, reaching oceanic crust late in the restricted phase or early in the oceanic phase. A combination of rapid basin subsidence (owing to thermal contraction, continued crustal thinning by oceanward creep, and/or sediment loading-Dingle, in press) and rapid erosion maintains a high sedimentation rate. 
Eventually separation is sufficient to connect this basin to the world ocean, establishing true oceanic conditions and ending the restricted-marine phase. The depocenter now is over oceanic crust, mainly on the continental rise, and sedimentation rates level out or fall off (Dingle, in press).

The sedimentary history of the margin from south of Cape Agulhas to Angola corresponds well with Dingle's (in press) model for tensional-clean-break margins. Tensional rifting in Early Cretaceous times created grabens in Angola (and probably under the continental shelf off South Africa) which were filled with continental sediments. After separation, restricted marine conditions were established, resulting in euxinic sediments to the south of Walvis Ridge (which acted as a barrier) and evaporites to the north. These deposits accumulated at a very rapid rate, initially over continental crust. Sediment depocenters prograded seaward with time, until deposition south of the Kunene River was located over oceanic crust towards the end of the restricted-marine phase (Aptian in the Cape Basin). However, salt diapirs north of the Kunene (e.g., in the Cuanza Basin) acted as sediment dams which delayed the shift from continental to oceanic crust until Late Cretaceous times off Angola (when the oceanic phase had become established) (Dingle, in press).

Widening of the South Atlantic established oceanic conditions at all sites by Albian times in the Cape Basin and Santonian times in the Angola Basin. Late Cretaceous sedimentation rates (Dingle's "oceanic phase") were considerably less than during the restricted-marine phase. Carbonate facies dominate in the Angola Basin during the oceanic phase, owing to the comparatively small discharge of the Kunene and Cuanza rivers. The Cape Basin still received considerable terrigenous sedimentation from the Orange River during this time.

Oceanic sedimentation continued through the Tertiary, with progressively falling sedimentation rates. Depocenters were located over the outer continental margin (over oceanic crust). Sediments were mostly biogenic calcareous oozes, mixed with a minor terrigenous fraction being transported across the shelf and down the slope. Modification in lithologies and sites and rates of accumulation of Tertiary sediments are more closely related to various oceanographic factors (notably current action, CCD and upwelling) than depositional environment.

This general sedimentary pattern resulted in rapid upward and outward building of the continental margin during the Cretaceous, with slow upbuilding and strong outbuilding (progradation) during the Cenozoic (Dingle, 1973a).

The cause of the periodic Cretaceous and Tertiary transgressions and regressions is unknown. The explanation could be (1) a change in sea-floor spreading rates, as tentatively suggested by Dingle and Scrutton (1974), or (2) an erosion-sedimentation imbalance, or (3) some combination of both (1) and (2). In the first hypothesis, a change in spreading rate would cause the elevation of the mid-ocean ridge to vary (Flemming and
Roberts, 1973), thereby increasing or decreasing ocean basin volume, which would cause a regression or transgression, respectively (other reasons have been proposed-see Vogt et al., 1971, for example).

The second hypothesis reasons that extensive erosion of the continental interior and deposition of sediment on the sea floor would gradually depress the coastal area, stimulating a transgression. Once a critical point in the isostatic imbalance was exceeded, the land mass would be re-uplifted to compensate, regression would occur, and the cycle would start again. Figure 2 shows that the Cenomanian, end-Miocene and end-Pliocene uplifts all correspond to the initiation of regressions; the Paleogene regressions, on the other hand, do not correspond to any known period of epeirogenic uplift.

\section{CONCLUSIONS}

The foregoing sections have attempted to relate the Leg 40 outer continental margin drilling results with geological events recorded on the continental shelf and onshore. Figures 2 and 3 summarize relevant data. Huge gaps are obviously still present in our knowledge, especially as to the sedimentological history of the continental shelf at depth. Thus, this synthesis should be regarded as a summary of the present state of our knowledge: much is known but much is yet to be learned, and many of the present interpretations will need to be modified as more data become available.

\section{ACKNOWLEDGMENTS}

This study forms part of the work of the joint Geological Survey/University of Cape Town Marine Geoscience Unit. Both organizations are thanked for their support. The management of Consolidated Diamond Mining (CDM) kindly gave permission and provided facilities for the writer to examine and sample outcrops in the Buntfeldschuh-Bogenfels area. A special word of thanks is owed to the staff of CDM for their field assistance and hospitality.

The writer is presently a member of the C.S.I.R. National Research Institute for Oceanology.

\section{REFERENCES}

Bandy, O.L., 1968. Cycles in Neogene palaeoceanography and eustatic changes: Palaeogeog., Palaeoclimatol., Palaeoecol., v. 5, p. 63-75.

Berggren, W.A. and Hollister, C.D., 1974. Paleogeography, paleobiogeography and the history of circulation in the Atlantic Ocean. In Hay, W.E. (Ed.), Studies in Paleooceanography: S.E.P.M. Spec. Pub. 20, Tulsa, p. 126-186.

Bornhold, B.D., 1973. Late Quaternary sedimentation in the Eastern Angola Basin: Ph.D.Thesis, M.I.T. and W.H.O.I, p. 213, Unpublished.

Bukry, D., 1974. Coccoliths as paleosalinity indicatorsEvidence from Black Sea. In Degens, E.T. and Ross, D.A. (Eds.), The Black Sea-geology, chemistry, and biology: A.A.P.G., Tulsa, Memoir 20, p. 353-633.

Bybell, L. and Gartner, S., 1972. Provincialism among midEocene calcareous nannofossils: Micropaleontology, v. 18 , p. 319-336.

De Swardt, A.M.J. and Bennet, G., 1974. Structural and physiographic development of Natal since the Late Jurassic: Geol. Soc. South Africa Trans., v. 77, p. $309-$ 322. 


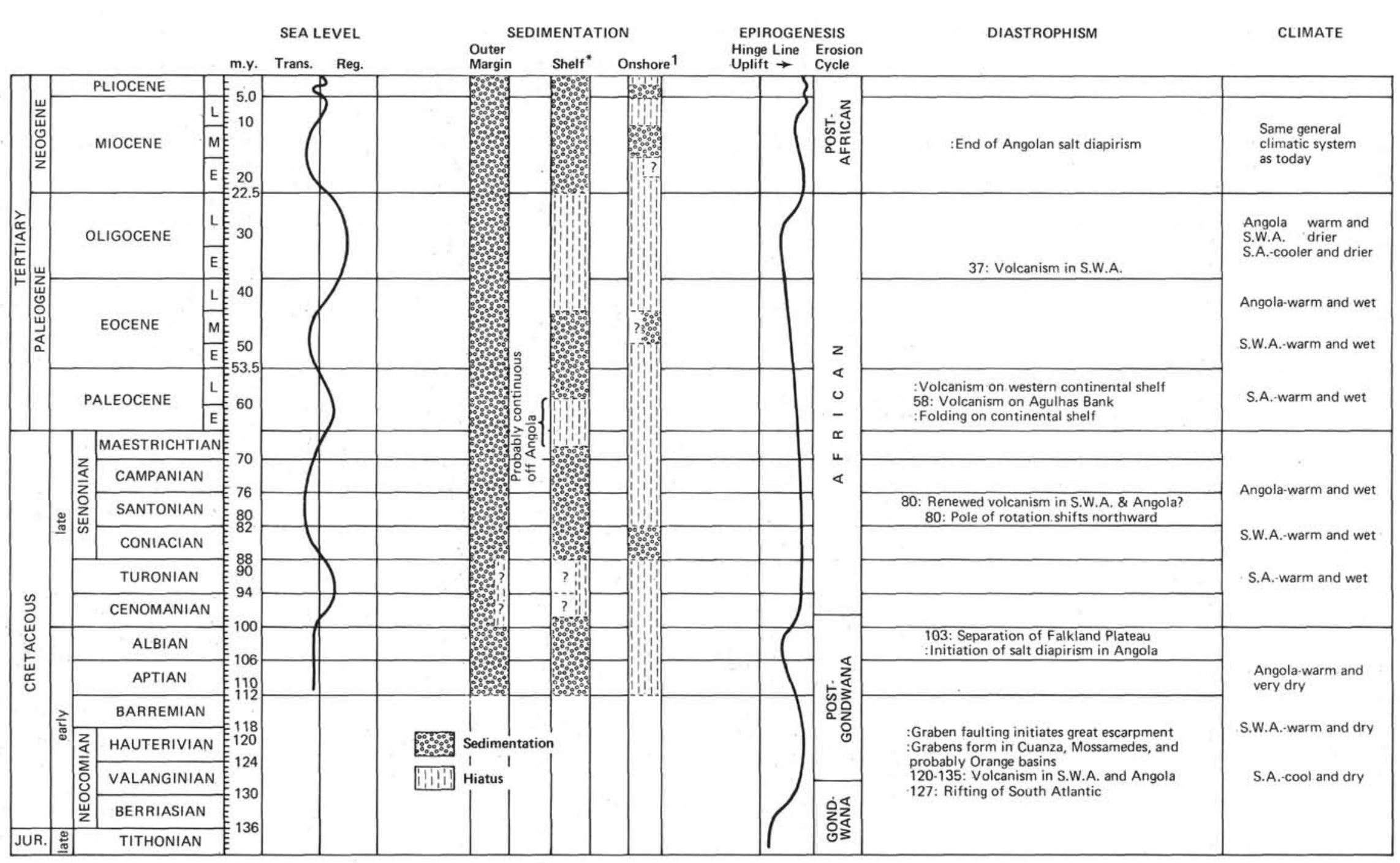

1 Marine sedimentation south of Kunene River
Largely speculative

Figure 2. Sea level changes, sedimentation, epeirogenesis, diastrophism, and climate from Early Cretaceous to Neogene (see text for data source). 


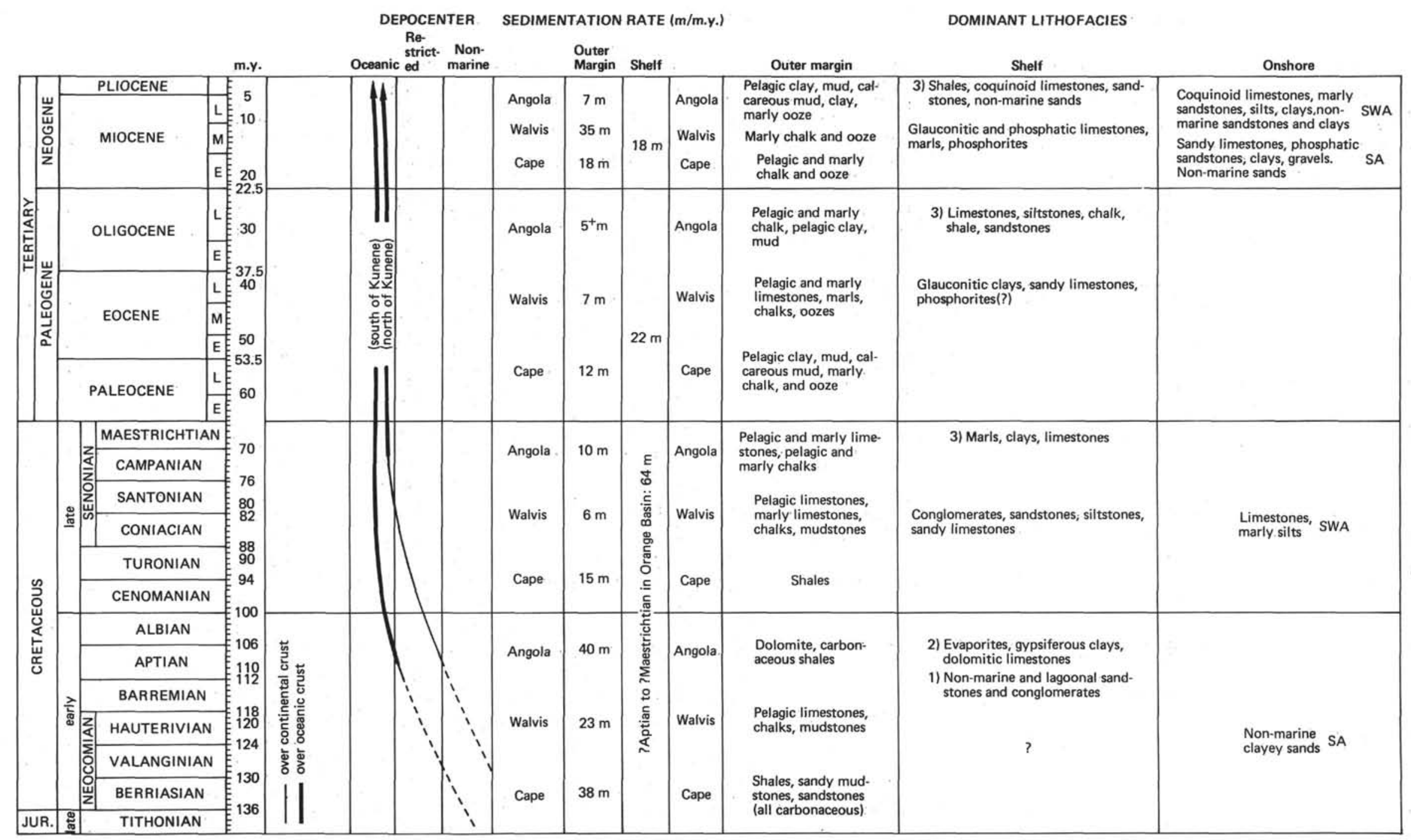

Figure 3. Depocenter migration, sedimentation rates, and sedimentary lithofacies from Early Cretaceous to Neogene (see text for data sources). 
Dietz, R.S. and Holden, J.C., 1970. Reconstruction of Pangaea: Breakup and dispersion of continents, Permian to present: J. Geophys. Res. v. 75, p. 4939-4956.

Dingle, R.V., 1971. Tertiary sedimentary history of the continental shelf off Southern Cape Province, South Africa: Geol. Soc. South Africa Trans., v. 74, p. 173-186.

1973a. The geology of the continental shelf between Lüderitz and Cape Town (Southwest Africa) with special reference to Tertiary strata: J. Geol. Soc., v. 129, p. 337-363.

, 1973b. Mesozoic palaeogeography of the southern Cape, South Africa: Palaeogeog., Palaeoclimatol., Palaeoecol., v. 13, p. 203-213.

1973c. Post-Paleozoic stratigraphy of the eastern Agulhas Bank, South African continental margin: Marine Geol., v. 15, p. 1-23.

1973d. Regional distribution and thickness of postPalaeozoic sediments on the continental margin of Southern Africa: Geol. Mag., v. 110, p. 97-208.

1974. Agulhas Bank phosphorites: a review of 100 years of investigation: Geol. Soc. South Africa Trans., v. 77 , p. $261-264$

in press. A review of the sedimentary history of some post-Permian continental margins of Atlantic-type: Ann. Brazil Acad. Sci.

Dingle, R.V. and Gentle, R.I., 1972. Early Tertiary volcanic rocks on the Agulhas Bank, South African continental shelf: Geol. Mag., v. 109, p. 127-136.

Dingle, R.V. and Scrutton, R.A., 1974. Continental breakup and the development of post-Paleozoic sedimentary basins around Southern Africa. Geol. Soc. Am. Bull., 85: 14671474.

Du Toit, A.L., 1954. The geology of South Africa, 3d Ed.: Edinburgh, (Oliver and Boyd).

Emery, K.O., Uchupi, E. Brown, C.O., Phillips, J., and Simpson, E.S.W., 1975. Continental margin off western Africa: Cape St. Francis (South Africa) to Walvis Ridge (South West Africa): Am. Assoc. Petrol. Geol. Bull., v. 59, p. 359.

Emery, K.O., Uchupi, E., Phillips, J., Brown, C., and Mascle, J., 1974. The continental margin off Western Africa, Angola to Sierra Leone: W.H.O.I. Tech. Rept. -74-99. (Unpublished manuscript.)

Flemming, N,C and Roberts, D.A., 1973. Tectono-eustatic changes in sea level and seafloor spreading: Nature, v. 243 , p. $19-22$.

Franks, L.A. and Kemp, E.M., 1972. Influence of continental positions of Early Tertiary climates: Nature, v. 240, p. 97. 100.

Franks, S. and Nairn, A.E.M., 1973. The equatorial marginal basins of West Africa. In The ocean basins and margins: the South Atlantic I: Nairn, A.E.M. and Stehli, F.G. (Eds.); New York, (Plenum Pub. Corp.) p. 301-350.

Greenman, L., 1969. The Elizabeth Bay Formation, Lüderitz, and its bearing on the genesis of dolomite: Geol. Soc. South Africa Trans., v. 72, p. 115-121.

Haughton, S.H., 1930a. Note on the occurrence of Upper Cretaceous marine beds in South West Africa: Roy. Soc. South Africa Trans., v. 33, p. 61-63.

1930 b. On the occurrence of Upper Cretaceous marine fossils near Bogenfels, S.W. Africa: Roy. Soc. South Africa Trans., v. 18, p. 361-365.

1963. Stratigraphic history of Africa south of the

Sahara: Edinburgh, (Oliver and Boyd).

1969. Geological history of Southern Africa: Cape Town, Geol. Soc. South Africa.

Hendey, Q.B., 1973. Fossil occurrences at Langebaanweg, Cape Province: Nature, v. 244, p. 13-14.
Kennedy, W.J. and Klinger, H.C., 1971. A major intraCretaceous unconformity in eastern South Africa: Geol. Soc. London J., v. 127, p. 183-186.

Kennett, J.P., Houtz, R.E., Andrews, P.B., Edwards, A.R., Gostin, V.A., Hajos, M., Hampton, M.A., Jenkins, D.G., Margolis, S.V., Ovenshine, A.T., and Perch-Nielsen, K., 1974. Development of the Circum-Antarctic Current: Science, v. 186, p. 144-147.

King, L.C., 1967. Scenery of South Africa. (2d. ed.) Edinburgh, (Oliver and Boyd).

Natal)

Korn, H. and Martin, H., 1937. Die Jüngere geologische und klimatische geschichte Sudwestafrikas: Centralbl. Mineralogie, Abt. B, p. 456-473.

Larson, R.L. and Ladd, J.W., 1973. Evidence for the opening of the South Atlantic in the early Cretaceous: Nature, v. 246 , p. $209-212$.

Le Pichon, X. and Hayes, D.E., 1971. Marginal offsets, fracture zones and the early opening of the South Atlantic: J. Geophys. Res., v. 76, p. 6283-6293.

Mabbutt, J.A., 1955. Erosion surfaces in Little Namaqualand and the ages of surface deposits in the South Western Kalahari: Trans. Geol. Soc. South Africa, v. 58, p. 13-29.

Marsh, J.S., 1973. Relationships between transform directions and alkaline igneous rock lineaments Africa and South America: Earth Planet. Sci. Lett., v. 18, p. 317-323.

Martin, H., 1973. The Atlantic margin of Southern Africa between latitude $17^{\circ}$ south and the Cape of Good Hope. In Nairn, A.E.M. and Stehli, F.G. (Eds.), The ocean basins and margins: the South Atlantic, I: New York (Plenum Pub. Corp.), p. 377-400.

Midgley, D.C., 1952. A preliminary survey of the surface water resources of the Union of South Africa: Ph.D. Thesis, Durban, (Natal Univ.).

Noël, D., 1965. Coccolithes Jurassiques. Essai de classification des coccolithes fossiles: C.N.R.S., Paris.

Roberts, D.G., 1975. Evaporite deposition in the Aptian South Atlantic Ocean: Marine Geol., v. 18, p. M65-M72.

Rogers, A.W., 1915. The occurrence of dinosaurs in Bushmanland: Roy. Soc. South Africa Trans., v. 5, p. $265-272$.

1922. Post-Cretaceous climates in South Africa: South Africa J. Sci., v. 19, p. 1-31.

Rooseboom, A. and Maas, N.F., 1974. Sediment-transport data for the Orange, Tugela and Pongola Rivers: Department of Water Affairs, Hydrology Division Tech. Rept. No. 59., Republic of South Africa.

Scrutton, R.A. and Dingle, R.V., 1974. Basement control over sedimentation on the continental margin west of Southern Africa. Geol. Soc. South Africa Trans., v. 77, p. 253-260.

Shackleton, N.J. and Kennett, J.P., 1975. Palaeotemperature history of the Cenozoic and the initiation of Antarctic glaciation: oxygen and carbon isotope analysis in DSDP sites 279, 277 and 281. In Kennett, J.P., Houtz, R.E., et al., Initial Reports of the Deep Sea Drilling Project, Volume 29: Washington (U.S. Government Printing Office), p. 801-808.

Siedner, G. and Miller, G.A., 1968. K-Ar age determinations on basaltic rocks from South West Africa and their bearing on continental drift: Earth Planet. Sci. Lett., v. 4, p. 451 .

Siesser, W.G., 1972. Petrology of the Cainozoic coastal limestones of the Cape Province, South Africa: Geol. Soc. South Africa, Trans., v. 75, p. 177-185.

Siesser, W.G., Scrutton, R.A., and Simpson, E.S.W., 1974. Atlantic and Indian Ocean margins of Southern Africa. In 
Burke, C.A. and Drake, C.L. (Eds.), The geology of continental margins: New York, (Springer-Verlag), p. 641654.

1975. Calcareous nannofossils from the South African continental margin: GSO/UCT Marine Geol. Prog. Bull. No. 5, Dept. Geol. Univ. Cape Town.

Tankard, A.J., 1974. Varswater formation of the Langebaanweg-Saldanha Area, Cape Province: Geol. Soc. South Africa Trans., v. 77, p. 265-283.

in press. Pleistocene history and coastal morphology of the Ysterfontein-Elands Bay area: Conference on Recent Progress in Later Cenozoic Studies in South Africa. South African Mus., Cape Town.
Truswell, J.F., 1970. An Introduction to the Historical Geology of South Africa: Cape Town, (Purnell \& Sons).

Van Zinderen Bakker, E.M., 1976. The evolution of lateQuaternary palaeo-climates of Southern Africa. In Van Zinderen Bakker, E.M. (Ed.), Palaeoecology of Africa IX: Cape Town, (Balkema), p. 1-46.

in press. The origin and palaeoenvironment of the Namib Desert biome. Jour. Biogeography.

Vogt, P.R., Johnson, G.L., Holcombe, T.L., Gilg, J.G., and Avery, O.E., 1971. Episodes of seafloor spreading recorded by the North Atlantic basement: Tectonophysics, v. 12, p. 211-234. 